\title{
KEEFEKTIFAN RELAKSASI NAFAS DALAM TERHADAP PENURUNAN STRES PADA LANSIA DI UPTD PELAYANAN SOSIAL LANJUT USIA TRESNA WERDHA NATAR LAMPUNG SELATAN
}

\author{
Rahma Elliya ${ }^{1}$, Yopita Sari ${ }^{2}$, Eka Yudha Chrisanto ${ }^{3}$
}

${ }^{1,3}$ Dosen Universitas Malahayati

E-mail: bundaauliyusri@yahoo.co.id

${ }^{2}$ Mahasiswa Program Studi Keperawatan Universitas Malahayati

E-mail: yopitasari122@gmail.com

\section{ABSTRACT: THE EFFECTIVENESS OF DEEP BREATHING RELAXATION TO ELDERLY REDUCED STRESS IN TRESNA WERDHA ELDERLY NURSING HOME IN NATAR OF SOUTH LAMPUNG DISTRICT}

Introduction: mental problems that often occur in elderly include stress, anxiety, and depression. The elderly suffered mental problems such as not precious feeling, loneliness, and lost. When these stressing conditions continue and are not mitigated immediately, then they would cause elderly's mental problems. The survey and observation 17 elderly suffered moderate stress with characteristics including easy to be fatigue, tensed back muscles, losing sleeping time, guilty feeling, fear and anxiety, hard beat chest, and trembling body.

Objective: the objective of this research was to find out the effectiveness of deep breathing relaxation to elderly reduced

Method: this was a quantitative and quasi-experiment research by using one group pretest and posttest design. Population was 17 respondents and samples were of total population. Data were analyzed by using dependent $t$-test by using DASS questionnaires with 14 items as measurement instrument.

Result: the average scores of stresses before and after breathing relaxation therapy 2019 were 21.53 and 16.29 respectively. The statistic test result derived p-value $0.000<$ a 0.05 .

Conclusion: Ther is aeffectivenessof deep breathing relaxation therapy to elderly reduced. The researcher suggests that the deep breathing relaxation therapy can be used to reduce elderly stress in TresnaWerdha Elderly Nursing Home. This therapy can be used as alternative medication concerning stress to mitigate psychological problems of elderly especially stress.

Keywords: Deep Breathing Relaxation, Stress Level ,Elderly

\section{INTISARI:KEEFEKTIFAN RELAKSASI NAFAS DALAM TERHADAP PENURUNAN STRES PADA LANSIA}

Pendahuluan : Masalah mental yang sering terjadi pada lansia adalah stres, kecemasan dan depresi. Lansia yang mengalami masalah mental mulai mengalami perasaan tidak berharga, kesepian dan kehilangan. Apabila kondisi stres ini terus menerus terjadi pada lansia dan tidak di atasi secepatnya maka akan berdampak kemasalah kejiwaan lansia. Hasil Survei dan Observasi didapatkan, 17 lansia dengan stres sedang, ciri-ciri fisik mudah lelah, otot punggung terasa tegang, kehilangan waktu tidur, perasaan bersalah, timbul 
perasaan ketakutan dan kecemasan, jantung berdebar-debar, serta badan sering gemetar.

Tujuan : Diketahui Keefektifan Relaksasi Nafas Dalam Terhadap Penurunan Tingkat Stres Pada Lansia.

Metode : Jenis Penelitian Kuantitatif, Rancangan Penelitian Quasi Experimen Design Dengan Pendekatan One Grup Pretes- Posttes Design. Populasi dalam Penelirian ini Sebanyak 17 responden dan Sampel Penelitian ini Menggunakan Total Sampling, Uji statistik menggunakan uji t-tes dependen dan menggunakan alat ukur DASS 14 item.

Hasil : Pada penelitian ini sebelum diberikan relaksasi nafas dalam didapat nilai mean 21,53 dan setelah diberikan terapi relaksasi nafas dalam didapat nilai mean 16,29 , hasil uji statistik didapatkan nilai $p$ value 0,000 dimana $p$ value $<a(0,05)$. Simpulan : Ada Keefektifan Relaksasi Nafas Dalam Terhadap Penurunan Stres Pada Lansia. Saran dari peneliti Teknik relaksasi nafas dalam dapat dijadikan pengobatan alternatif dalam panti khususnya tentang stres serta mampu menanggulangi masalah psikologis lansia terutama masalah stres yang muncu

Kata Kunci: Relaksasi Nafas Dalam, Stres, Lansia

\section{PENDAHULUAN}

Menua atau menjadi tua adalah suatu keadaan yang terjadi di dalam kehidupan manusia. Proses menua merupakan proses sepanjang hidup, tidak hanya di mulai dari suatu waktu tertentu, tetapi di mulai sejak permulaan kehidupan. Menjadi tua merupakan proses alamiah, yang berarti seseorang telah melalui tiga tahap kehidupannya, yaitu anak, dewasa, dan tua. Tiga tahap ini berbeda, baik secara biologis maupun psikologis. Memasuki usia tua berarti mengalami kemunduran, misalnya kemunduran fisik yang di tandai dengan kulit yang mengendur, rambut memutih, gigi mulai ompong, pendengaran kurang jelas, penglihatan semakin memburuk, gerakan lambat, dan figur tubuh yang tidak proporsional (Nugroho, 2017).

Badan Kesehatan Dunia (WHO) menyebutkan bahwa umur 60 tahun adalah usia permulaan tua. Menua bukanlah suatu penyakit, tetapi merupakan proses yang berangsur-angsur mengakibatkan perubahan yang kumulatif. Proses menua merupakan Proses menurunnyadaya tahan tubuh dalam menghadapi rangsangan dari dalam dan luar tubuh yang berakhir denga kematian (Nugroho, 2017).

Distress (Stres buruk) adalah stres yang bersifat negatif. Distres dihasilkan dari sebuah proses sesuatu yang buruk, dimana respons yang digunakan selalu negatif dan ada indikasi mengganggu integritas diri sehingga bisa diartikan sebuah ancaman. Distres akan menempatkan pikiran dan perasaan kita pada tempat dan suasana yang serba sulit. Hal tersebut dikarenakan cara memandang suatu masalah hanya dilihat dari sisi yang sempit dan merugikan saja (Nasir \& Muhith, 2011).

Masalah mental yang sering terjadi pada lansia adalah stres, kecemasan dan depresi. Lansia yang mengalami masalah mental mulai mengalami perasaan tidak berharga, kesepian dan 
kehilangan. Keadaan yang paling rentan dialami oleh lansia dan berpotensi menjadi sumber tekanan dalam hidup adalah stres (Stanley \& Barre, 2007; Putri, 2012). Stres pada lansia dapat didefinisikan sebagai tekanan yang diakibatkan oleh stresor berupa perubahanperubahan yang menuntut adanya penyesuaian diri lansia. Tingkat stres pada lansia berarti pula tinggi rendahnya tekanan yang dirasakan atau yang dialami oleh lansia sebagai akibat dari stresor berupa perubahanperubahan baik fisik, mental, maupun sosial dalam kehidupan yang dialami lansia (Indriana, 2010; Novitasari \& Aryana, 2013). Beberapa faktor-faktor yang mempengaruhi stres pada lansia meliputi kondisi kesehatan fisik, kondisi psikologi, keluarga, lingkungan, pekerjaan (Fitria, 2007; Novitasari \& Aryana, 2013). Apabila kondisi stres ini terus menerus terjadi pada lansia dan tidak di atasi secepatnya maka akan berdampak kemasalah kejiwaan lansia (Lestari, 2015; Priyoto, 2016).

Berdasarkan Data Proyeksi Penduduk Tahun 2017 terdapat 23,66 juta jiwa penduduk lansia di Indonesia (9,03\%). Di prediksi jumlah penduduk lansia tahun 2020 (27,08 juta), tahun 2025 (33,69 juta), tahun 2030 (40,95 juta) dan tahun 2035 (48,19 juta) (Kementrian Kesehatan Republik Indonesia, 2017). Berdasarkan Data dari Badan Pusat Statistik Provinsi Lampung Tahun 2016 Lansia dengan Umur 60-54 terdapat 215.230 jiwa dan umur 65+ terdapat 391.318 jiwa (Badan Pusat Satistik Provinsi Lampung, 2016).
Peningkatan jumlah penduduk lansia apabila tidak segera ditangani akan menambahkan masalah yang sangat kompleks, terutama di bidang kesehatan mengingat lansia merupakan periode dimana organisme telah mencapai kemasakan dalam ukuran dan fungsi yang telah menunjukan kemunduran sejalan dengan waktu. Masa tua banyak menghadapi berbagai asalah kesehatan yang perlu penanganan dengan baik, seperti diketahui bahwa memasuki lansia identik dengan menurunnya daya tahan tubuh dan mengalami berbagai penyakit degeneratif yang menyerang. Keadaan tersebut berpengaruh pada permasalahan kondisi ketahanan tubuh lansia yang diterimanya dari lingkungan sekitar, maka tekanan atau stresor pada diri lansia berpengaruh pada rasa kecemasan dan stres. Lansia mudah mudah mengalami stres karena fungsi dari kemampuan menyelesakan masalah (mekansme koping) juga menurun (Anderson, 2008; Rosita, 2012).

Teknik relaksasi merupakan salah satu bentuk manajemen stres dalam upaya melakukan modifikasi gaya hidup. Teknik relaksasi (non-farmakologis) yang adalah Relaksasi Otot (Progressive muscle relaxation), (diaphragmatic breathing), Meditasi (attention- faccusing exercises), dan Relaksasi Prilaku (behavioral relaxation training), (schwickert, 2006; Hamarno, 2010). Teknik relaksasi nafas dalam merupakan salah satu terapi relaksasi yang mampu membuat tubuh menjadi lebih tenang dan harmonis, serta mampu memberdayakan 
tubuhnya untuk mengatasi gangguan yang menyerangnya. Teknik relaksasi nafas dalam merupakan suatu teknik untuk melakukan nafas dalam, nafas lambat (menahan inspirasi secara maksimal) dan bagaimana menghembuskan nafas secara perlahan. Teknik relaksasi nafas dalam juga dapat menigkatkan ventilasi faru dan meningkatkan oksigen dalam darah (Suwardianto, 2011). Salah satu upaya untuk mengatasi stres Lansia adalah dengan metode relaksasi. Hal itu karena dalam relaksasi terkandung unsur penenangan diri.(Novitasari \& Aryana, 2013).

Relaksasi Nafas Dalam adalah pernafasan abdomen dengan frekuensi lambat atau perlahan, berirama dan nyaman yang dilakukan dengan memejamkan mata (Setyoadi \& Kushariyadi, 2011). Tujuan relaksasi nafas dalam adalah untuk meningkatkan ventilasi alveoli, memelihara pertukaran gas mencegah atelektasi paru, merelaksasikan teganggan otot, meningkatkan efesiensi batuk, mengurangi stres baik stres fisik maupun emosional yaitu menurunkan intensitas nyeri (mengontrol atau mengurangi nyeri) dan menurunkan cemas (Nasuha, Widodo \& Widiani, 2015). Kelebihan latihan teknik relaksasi dari pada latihan yang lain adalah latihan relaksasi lebih mudah dilakukan bahkan dalam kondisi apapun serta tidak memiliki efek samping apapun (Novitasari \& Aryana, 2013). Disamping itu tehnik relaksasi lebih mudah dilaksanakan oleh pasien, dapat menekan biaya pengobatan, dan dapat digunakan untuk mencegah terjadinya stres. Sedangkan kita tahu pemberian obat-obatan kimia dalam jangka waktu lama dapat menimbulkan efek samping yang dapat membahayakan pemakainya seperti gangguan pada ginjal (Yosep, 2007; Novitasari \& Aryana, 2013).

Berdasarkan hasil wawancara dengan kepala seksi Pelayanan Panti Sosial Lanjut Usia Tresna Werdha di proleh data, Lansia Pria 39 orang, Lansia Wanita 47 orang. Total pasien lanjut usia di Panti Sosial Lanjut Usia Tresna Werdha adalah 86 orang. Setelah dilakukan Survei dan Observasi dengan pengurus-pengurus wisma di dapatkan laporan bahwah 17 orang lansia yang mengalami stres, dengan ciriciri, tiba-tiba menangis saat ada yang bertanya atau mendekati, marah-marah dengan rekan satu kamar, suka membanting barang yang terdekat, merasa tidak sabar terhadap hal yang dilakukan, setelah dilakukan pengukuran dengan DASS 14 item didapatkan, 17 lansia stres sedang, dengan ciri-ciri fisik mudah lelah, otot punggung terasa tegang, kehilangan waktu tidur, perasaan bersalah, timbul perasaan ketakutan dan kecemasan, jantung berdebardebar, serta badan sering gemetar. Kepala seksi pelayanan tersebut mengatakan dalam mengatasi stres lansia, pihak panti mengadakan kegiatan rekreasi setiap satu tahun sekali dan kegiatan kerohanian tiga kali seminggu meliputi terapi murotal Al-qur'an, serta bimbingan keagamaan yakni pada hari senin, selasa dan jum'at, selain itu dari pihak panti juga melakukan kegiatan kemasyarakatan dan keterampilan, namun kegiatan ini di akui oleh kepala seksi 
pelayanan tersebut masih belum efektif untuk mengurangi stres pada lansia. Trapi Relaksasi Nafas Dalam tidak ada dalam jadwal kegiatan lansia, terapi relaksasi hanya di lakukan jika ada mahasiswa yang melakukan praktek di Panti Sosial Lanjut Usia Tresna Werdha.

Hasil penelusuran penulis yang berjudul Pengaruh Teknik Relaksasi Nafas Dalam Terhadap Tingkat Kecemasan Pada Lansia di Posyandu Lansia RW IV Dusun Dempok Desa Gading Kembar Kecamatan Jabung Kabupaten Malang. Penelitian tersebut menunjukan ada perbedaan yang siknifikan terhadap tingkat Kecemasan lansia sebelum dan sesudah di berikan teknik relaksasi Nafas Dalam (Nasuha, Widodo \& Widiani, 2015).

Melihat Fenomena diatas maka peneliti sangat tertarik untuk melakukan penelitian mengenai Keefektifas Relaksasi Nafas Dalam Terhadap Penurunan Stres Lansia Di UPTD Pelayanan Sosial Lanjut Usia Tresna Werdha Natar Lampung Selatan.

\section{METODE PENELITIAN}

Jenis penelitian yang digunakan dalam penelitian ini adalah jenis penelitian kuantitatif. Penelitian ini menggunakan rancangan Quasi Experiment Design dengan pendekatan One grup pretest Posttest design. Populasi dalam penelitian ini adalah seluruh lansia yang mengalami stress di Panti Sosial Lanjut Usia Tresna Werdha Natar Lampung Selatan, populasi dalam penelitian ini berjumlah 17 orang. Sampel pada penelitian ini berjumlah 17 orang. Teknik Sampling pada penelitian ini adalah Total Sampling. Penelitian ini di laksanakan di Panti Sosial Lanjut Usia Tresna Werdha Natar Lampung selatan dan waktu penelitian di laksanakan pada tanggal 24 Juni - 02 Juli 2019. Alat pengumpul data pada penelitian ini adalah dengan menggunakan lembar kuesioner Dass 14 item. Terapi relaksasi nafas dalam diberikan pada responden dengan terlebih dahulu memberikan standar operasional (SOP) cara melakukan terapi relaksasi nafas dalam. Uji ini dilakukan untuk mengidentifikasi hubungan variable bebas dan variable terikat. Uji statistik menggunakan uji $t$ dependen dengan tingkat kemaknaan 95\% (a 0,05). 
Tabel 1

Distribusi Frekuensi Berdasarkan Karakteristik Pasien

\begin{tabular}{lcc}
\hline \multicolumn{1}{c}{ Karakteristik } & Jumlah & Persentasi \\
\hline Usia : & 7 & \\
- 62-66 tahun & 10 & 35,3 \\
- $71-78$ tahun & 1 & 58,8 \\
- 89 tahun & 5 & 5 \\
Status Perkawinan: & 12 & 29,4 \\
- Menika & & 70,6 \\
- Janda /duda & 11 & \\
Jenis Kelamin : & 6 & 64,7 \\
- Perempuan & & 35,3 \\
- Laki- Laki & 9 & \\
Riwayat Penyakit : & 8 & 52,9 \\
- Hipertensi & 0 & 0 \\
- Asam Urat & & \\
- Lain-Lain & 0 & 0 \\
Lama dipanti : & 7 & 41,2 \\
- <1 Tahun Tahun & 10 & 58,8 \\
- > 1- 5 Tahun & 17 & 100.0 \\
- >5 Tahun & & \\
Total & & \\
\hline
\end{tabular}

diketahui bahwa sebagian besar responden dengan rentan usia 71-78 tahun yaitu sebanyak 10 responden $(58,8 \%)$, yang bersetatus janda/ duda sebanyak 12 responden $(70,6 \%)$, serta yang memiliki riwayat penyakit hipertensi 9 responden $(52,9 \%)$, memiliki jenis kelamin perempuan 11 responden (64,7\%), dan lama dipanti lebih dari 5 tahun 10 responden $(58,8 \%)$.

Tabel 2.

Stres Sebelum dilakukan Terapi Relaksasi Nafas Dalam

\begin{tabular}{lcccc}
\hline \multicolumn{1}{c}{ Variabel } & $\mathbf{N}$ & Mean & SD & Min-Max \\
\hline $\begin{array}{l}\text { Stres Sebelum } \\
\text { dilakukan Terapi }\end{array}$ & 17 & 21,53 & 2,239 & $19-25$ \\
$\begin{array}{l}\text { Relaksasi Nafas } \\
\text { Dalam }\end{array}$ & & & & \\
\hline
\end{tabular}

Dari tabel 2 diatas dapat diketahui bahwa stres lansia dari 17 responsen dengan stres sedang dilakukan Terapi Relaksasi Nafas Dalam di UPTD Pelayanan Sosial Lanjut Usia
Tresna Werdha Natar Lampung Selatan Tahun 2019 dengan mean 21,53 nilai min 19 max 25 dan standar deviasi 2,239

Tabel 3. 
Stres sesudah dilakukan Terapi Relaksasi Nafas Dalam

\begin{tabular}{ccccc}
\hline Variabel & N & Mean & SD & Min-Max \\
\hline $\begin{array}{c}\text { Stres Setelah } \\
\text { dilakukan Terapi }\end{array}$ & 17 & 16,29 & 1,611 & $14-20$ \\
$\begin{array}{c}\text { Relaksasi Nafas } \\
\text { Dalam }\end{array}$ & & & & \\
\hline
\end{tabular}

Dari tabel 3 diatas setelah dilakukan Terapi Relaksasi Nafas Dalam di UPTD Pelayanan Sosial Lanjut Usia Tresna Werdha Natar Lampung Selatan Tahun
2019 dapat diketahui bahwa 17 responden dengan stres ringan dengan mean 16,29 nilai min 14 $\max 20$ dan standar deviasi 1,611

Tabel 4

Keefektifan Relaksasi Nafas Dalam Terhadap Penurunan Stres Pada Lansia Di UPTD Pelayanan Sosial Lanjut Usia Tresna Werdha Natar Lampung Selatan

Tahun 2019

\begin{tabular}{cccccc} 
Variabel & Mean & SD & t & p value & $95 \% \mathrm{Cl}$ \\
\hline Pretest & 21,53 & 2,239 & 11,430 &, 000 & $4,264-6,206$ \\
Posttest & 16,29 & 1,611 & & &
\end{tabular}

Dari tabel 4 terlihat bahwa rata-rata stres sebelum diberikan tindakan terapi relaksasi nafas dalam 17 responden dengan stres dengan mean 21,53 dan standar deviasi 2,239 pada pengukuran posttes didapatkan 17 responden stres ringan rata-rata hasil pengaruh sesudah dilakukan pemberian terapi relaksasi nafas dalam dengan mean 16,29 dan standar deviasi 1,611 dan

\section{PEMBAHASAN}

Beradasarkan hasil penelitian menunjukan ada Keefektifan pemberian terapi Relaksasi Nafas Dalam Terhadap Penurunan Stres Pada Lansia Di UPTD Pelayanan Sosial Lanjut Usia Tresna Werdha Natar Lampung Selatan Tahun 2019 setelah dilakukan pemberian terapi relaksasi nafas dalam diperoleh nilai rata-rata mean 16,29 dan standar deviasi 1,611 hasil uji statistic didapatkan nilai $p$ value $=0,000$ dengan $16 \quad(94,2 \%) \quad$ Responden berubah menjadi $2(11,8 \%)$ stres normal, dan 14 (82,4\%) Stres Ringan selisih Mean 5,24. Hasil uji statistic didapatkan nilai $p$-value $0,000 \mathrm{Hal}$ ini dapat disimpulkan bahwa ada keefektifan relaksasi nafas dalam terhadap penurunan stres sebelum dan sesudah diberikan terapi Relaksasi Nafas Dalam Pada Lansia Di UPTD Pelayanan Sosial Lanjut Usia Tresna Werdha Natar Lampung Selatan Tahun 2019.

dengan nilai mean 16,29 dan standar deviasi 1,611.

Hal ini menunjukan bahwa pengobatan stres pada lansia tidak slalu menggunakan penanganan medis atau farmakologi, terapi relaksasi nafas dalam bersifat sebagai teraupetik dan bersifat menyembuhkan. Relaksasi nafas dalam adalah pernafasan abdomen dengan frekuensi lambat atau perlahan beriramah dan nyaman yang dilakukan dengan memejamkan mata (Kushariyadi, 2011). Proses pernafasan yang tepat merupakan penawar stres. Proses pernafasan merupakan proses masuknya Oksigen melalui saluran nafas kemudian 
masuk keparu dan di proses kedalam tubuh kemudian selanjutnya di proses kedalam paru tepatnya di bronkus dan diedarkan keseluruh tubuh melalui pembuluh vena dan nadi untuk memenuhi kebutuhan akan Oksigen. Apa bila Oksigen dalam otak tercukupi maka manusia berada dalam kondisi seimbang. Kondisi ini akan menimbulkan keadaan rileks secara umum pada manusia. Perasaan rileks akan di teruskan kehipotalamus untuk menghasilkan Corticotropin Releasing factor (CRF). Selanjutnya CRF merangsang kelenjar dibawah otak untuk meningkatkan produksi Proopioidmelanocortin (POMC) sehingga produksi Enkephalin oleh Medula Adrenal meningkat. Kelenjar dibawah otak juga menghasilkan $\beta$ endorphin sebagai neurotransmitter yang mempengaruhi suasana hati menjadi rileks. Meningkatnya enkephalin dan $\beta$ endorphin kebutuhan tidur akan terpenuhi dan lansia akan merasa lebih rileks dan nyaman (Taylor, 2001;Risna, 2005; Novitasari \& Aryana, 2013).

Hasil Penelitian ini Sejalan dengan penelitian yang berjudul Pengaruh Tehnik Relaksasi Benson (Relaksasi Nafas yang Melibatkan Keyakinan Pasien) Terhadap Penurunan Tingkat Stres Lansia di Unit Rehabilitas Sosial Wening Wardoyo Unggara. Kesimpulan yang dapat di tarik yaitu ada perbedaan yang siknifikan terhadap Stres Lansia Sebelum dan Sesudah di berikan teknik relaksasi Benson (Relaksasi Nafas yang Melibatkan Keyakinan Pasien) pada kelompok intervensi diunit rehabilitas sosial wening wardoyo ungaran didapatkan nilai $t$ hitung sebesar 4,519 dengan $p$-value $0,000>\alpha(0,05) \quad$ (Aryana \& Novitasari, 2013).

Menurut analisa peneliti terapi relaksasi nafas dalam terhadap penurunan stres pada lansia di UPTD pelayanan sosial lanjut usia tresna werdha natar lampung selatan tahun 2019 sangat efektif dilakukan karna terapi Relaksasi Nafas Dalam adalah pernafasan abdomen dengan frekuensi lambat atau perlahan, berirama dan nyaman yang dilakukan dengan memejamkan mata. Tujuan relaksasi nafas dalam adalah untuk meningkatkan ventilasi alveoli, memelihara pertukaran gas mencegah atelektasi paru, merelaksasikan teganggan otot, meningkatkan efesiensi batuk, mengurangi stres baik stres fisik maupun emosional dan menurunkan cemas. Kelebihan latihan teknik relaksasi dari pada latihan yang lain adalah latihan relaksasi lebih mudah dilakukan bahkan dalam kondisi apapun serta tidak memiliki efek samping apapun. Disamping itu tehnik relaksasi lebih mudah dilakukan bahkan dalam kondisi apapun serta tidak memiliki efek samping apapun, disamping itu dapat menekan biaya pengobatan, dan dapat digunakan untuk mencegah terjadinya stres. Sedangkan kita tahu pemberian obat-obatan kimia dalam jangka waktu lama dapat menimbulkan efek samping yang dapat membahayakan pemakainya seperti gangguan pada ginjal.

Menurut analisa peneliti 17 $(100 \%)$ responsen dengan stres sedang sebelum dilakukan relaksasi nafas dalam diperoleh nilai mean 21,53 nilai min $19 \max 25$ dan standar deviasi 2,239. Setelah diberikan terapi relaksasi nafas dalam diperoleh nilai rata-rata mean 16,29 dan standar deviasi 1,611 hasil uji statistic didapatkan nilai $p$ value $=$ 0,000 dengan 16 (94,2\%) Responden berubah menjadi $2(11,8 \%)$ stres normal, dan 14 (82,4\%) Stres Ringan dengan nilai mean 16,29 dan standar deviasi 1,611. Sebagian besar lansia yang berada dipanti werdha mengalami stres sedang yang di sebapkan karena kekecewaan atau 
kemarahan pada anak, keluarga atau lingkungan sekitar. Stres sedang biasanya disertai keluhan seperti gangguan tidur, detak jantung lebih keras, ketegangan emosional meningkat. Selain mengalami stres sedang lansia juga ada yang mengalami stres ringan ini disebapkan karena terlalu banyak tidur. Situasi seperti ini beberapa menit atau jam. bagi mereka sendiri, stres ini bukan resiko yang signifikan untuk timbulnya gejal, namun demikian, stresor yang banyak dalam waktu singkat dapat meningkatkan resiko penyakit.

Seseorang yang mengalami stres akan membuat segala macam atau tuntutan penyesuaian diri, dan karena itu, sesuatu yang menggangu keseimbangan. Terkadang stres ini dapat turun dengan sendirinya karena seseorang yang mengalami stres dapat menenangkan dirinya sendiri dalam arti seseorang ini menanggapi stres atau respon seseorang terhadap stres tersebut tidak berlebihan, jika tanggapan atau respon seseorang terhadap stres tidak berlebihan, jika tanggapan atau strain itu berlebihan ini akan menjadi sebuh ketegangan atau tekanan yang akan membuat pola pikir, emosi dan perilaku akan menjadi kacau, ini yang akan menyebapkan stres. Maka dari itu stres dapat turun dengan sendirinya tergantunng bagaimana seseorang menyikapi stres tersebut.

Menurut analisa peneliti teknik relaksasi sangat efektif dilakukan hal ini karena dalam relaksasi terkandung unsur penenangan diri. Relaksasi nafas dalam adalah pernafasan abdomen dengan frekuensi lambat atau perlahan berirama dan nyaman yang dilakukan dengan memejamkan mata. Secara umum lansia sebelum dan sesuah diberikan terapi relaksasi nafas dalam rata-rata hampir semua mengalami penurunan stres. Karena mereka telah di ajarkan bagaimana cara menurunkan stres dengan terapi relaksasi nafas dalam secara rutin.

Stres yang berlebihan akan berdanpak pada kejiwaan lansia. Pada lansia yang dilakukan intervensi namun tidak mengalami penurunan stres dikarnakan faktor kurangnya keyakinan, atau pemahaman terhadap manfaat terapi relaksasi nafas dalam itu sendiri, faktor lain adalah tingkat stres lansia sudah terlalu tinggi bahkan kronis, sehingga tidak bisa jika hanya dilakukan dengan relaksasi nafas dalam saja, tetapi harus dilakukan dengan pengobatan yang lebih serius (psikiater atau ahli kejiwaan) bahkan rumah sakit jiwa.

\section{KESIMPULAN}

1. Diketahui sebelum diberian terapi relaksasi nafas dalam didapatkan $17 \quad(100 \%)$ responden mengalami stres sedang dengan nilai mean 21,53 dan standar deviasi 2,239 .

2. Diketahi setelah diberikan terapi relaksasi nafas dalam pada lansia di UPTD pelayanan sosial lanjut usia tresna werdha natar lampung selatan tahun 2019 diperoleh nilai $\rho$ value $=0,000$ dengan $16 \quad(94,2 \%) \quad$ Responden berubah menjadi $2(11,8 \%)$ stres normal, dan $14(82,4 \%)$ Stres Ringan dengan nilai mean 16,29 dan standar deviasi 1,611.

3. Diketahui keefektifan relaksasi nafas dalam terhadap penurunan stres lansia di UPTD Pelayanan Sosial Lanjut Usia Tresna Werdha Natar Lampung Selatan dengan nilai mean 21,53 sebelum diberikan terapi relaksasi nafas dalam, dan nilai mean 16,29 setelah 
diberikan terapi relaksasi nafas dalam.

\section{SARAN}

1. Instansi Panti Sosial Teresna Werdha Natar Lampung Selatan Teknik relaksasi nafas dalam dapat dijadikan pengobatan alternatif dalam panti khususnya tentang stres serta mampu menanggulangi masalah psikologis lansia terutama masalah stres yang muncu.

2. Peneliti Selanjutnya

Hendaknya mampu mengotrol faktor-faktor yang mempengaruhi stres lansia, seperti tipe prilaku lansia saat beradaptasi dengan lingkungan misalnya harapan sosial yang terlalu tinggi, pelayanan yang buruk, hubungan sosial yang buruk

\section{DAFTAR PUSTAKA}

Aryana, K. O., Novitasari, D. (2013). Pengaruh Tehnik Relaksasi Benson Terhadap Penurunan Tingkat Stres Lansia Di Unit Rehabilitas Sosial Wening Wardoyo Ungaran. Jurnal Keperawatan Jiwa, 1(2).

\section{Badan Pusat Satistik Provinsi Lampung. (2015). Jumlah Penduduk menurut kelompok umur dan jenis kelamin di Provinsi Lampung.}

Fitria. (2007). Prinsip Dasar dan Aplikasi Penulisan Laporan Pendahuluan dan Strategi Pelakasanaan tindakan keperawatan. Jakarta : Salemba Medika

Harmono, R. (2010). Pengaruh Latihan Relaksasi Otot Progresif terhadap Penurunan Tekanan
Darah Klien Hipertensi Primer di Kota Malang , Tesis Program Studi Magister Ilmu Keperawatan Fakultas Keperawatan Universitas Indonesia. Depok.

Indriana Y. (2010). Tingkat Stres Pada Lansia dipanti werdha pucanggading semarang, Jurnal Psikologi Undip.

Kementrian Kesehatan Republik Indonesia. (2017). Analisis lansia di Indonesia. Jakarta: Pusat Data dan Informasi

Kushariyadi. (2012). Asuhan Keperawatan pada Klien Lanjut Usia. Jakarta: Salemba Medika.

Lestari, Titik.(2015). Kumpulan Teori untuk Kajian Pustaka Penelitian Kesehatan. Yogyakarta: Nuha Medika.

Nasir. A., Muhith, A. (2011). Dasardasar keperawatan jiwa: pengantar dan teori. Jakarta: Salemba Medika.

Nasuha, N., Widodo, D., Widiani, E. (2016). Pengaruh Teknik Relaksasi Nafas Dalam Terhadap Tingkat Kecemasan Pada Lansia di Posyandu Lansia RW IV Dusun Dempok Desa Gading Kembar Kecamatan Jabung Kabupaten Malang. Nursing News: Jurnal Ilmiah Mahasiswa Keperawatan, $1(2)$.

Nugroho, W. (2017). Keperawatan gerontik \& geriatrik edisi 3. Jakarta: EGC.

Priyoto. (2016). Perbedaan Tingkat Stres Pada Lansia Yang Tinggal Bersama Keluarga di Desa Tebon Kecamatan Barat Kabupaten Magetan dan di UPT PSLU (Pelayanan Sosial Lanjut Usia) 
Kecamatan Selosari Kabupaten Magetan. Surya. Vol 08, No.02, https: / /jurnal.stikesmuhla.ac.i d/wp-

content/uploads/2016/12/6470-Priyoto.pdf.

Putri. R. D. (2012). "Perbedaan Tingkat Stres Pada Lansia Yang Bertempat Tinggal di Rumah Dan di UPT Pelayanan Sosial Lanjut Usia Bondowoso."

Resti, I. B. (2014). Teknik relaksasi otot progresif untuk mengurangi stres pada penderita asma. Jurnal Ilmiah Psikologi Terapan, 2(1), 01-20

Rosita, (2012). Stressor Sosial Biologis Lansia Panti Werdha Usia dan Lansia Tinggal Bersama Keluarga.

Risna, N. (2005). Pengaruh relaksasi benson terhadap pemenuhan kebutuhan tidur pada lansia, jurnal kesehatan

Setyoadi, K. (2011). Terapi modalitas keperawatan pada klien psikogeriatrik. Jakarta: Salemba Medika

Suwardianto, H., Kurnia, E. (2011). Pengaruh Terapi Relaksasi Nafas Dalam (deep Breathing) terhadap penurunan tekanan darah pada penderita Hipertensi dipuskesmas Kota Wilaya Selatan Kediri.

Stanley., Beare. (2007). Buku Ajar keperawatan gerontik. Edisi 2. Alih bahasa Juniarti dan Kurnianingsih. Jakarta : EGC.

Yosep, I. (2007). Keperawatan jiwa. Bandung: PT Refika Aditama. 